\title{
Den glemte historie \\ Bemærkninger til et godt nyt initiativ \\ - og et par advarsler
}

\author{
af Ole Lange
}

I

Det er en udbredt opfattelse, at beskæftigelse med fortiden er perspektivløs og intet giver, når man skal planlægge fremtiden. Den opfattelse er forkert. På Constantin Hansens berømte maleri på Frederiksborg af den grundlovgivende rigsforsamling er de centrale figurer lensgreve A. G. Moltke, Bregentved, som den første statsminister, C. C. Hall, D. G. Monrad, Orla Lehmann og Carl Ploug. De er de officielle frontfigurer som samtiden og Constantin Hansen så dem.

Men de virkeligt centrale personer i den proces, der førte op til Grundloven. af 1849 , og som spillede en rolle i den følgende udvikling, er ikke med som centrale personer på billedet.

To af dem skal nævnes som eksempler.

Den ene er botanik-professoren J. F. Schouw. Han står noget ude til venstre i billedet - et stykke borte fra den centrale gruppe.

Schouw var en af veteranerne i den liberale oppositionsbevægelse, der fra 1830 'rne arbejdede for en fri forfatning. En klogt mådeholden dirigent diskret, men helt central i processen.

Den anden nøgleperson med en endnu mere beskeden placering på dette officielle billede er Grundtvig. Han skimtes med sit karakteristiske hoved langt i baggrunden mellem Plougs og Lehmanns fyldige korpus, men dog $i$ et af billedets krydsperspektiver.

Historisk set har Schouw og Grundtvig en langt vigtigere placering end billedets centrale figur - lensgreven fra Bregentved. Reelt var han kun en prydelig kransekagefigur.

Det gik ikke op for samtiden. Først eftertiden har set det.

Hvis dette grundlovsbillede skulle males $i$ dag, ville placeringen være anderledes end på Constantin Hansens officielle fremstilling.

II

På samme måde forholder det sig med idrættens eller kropskulturens historie gennem de seneste godt 100 år. Den har den samme placering i det samlede billede af Danmarkshistorien som Schouw og Grundtvig hos Con- 
stantin Hansen.

Det ses af den placering, som sport og kropskultur er tildelt i den senest udkomne samlede fremstilling af dansk historie, Politikens Danmarks Historie. I bind 12, De nye Klasser, der dækker kropskulturens første vækstperiode 1870-1914, er der eet kapitel med titlen Sport og Fornøjelser. Det er på små 27 sider!

Heraf er sporten tildelt de 10, inclusive billeder. De andre afsnit i dette kapitel har overskrifter som Offentlige Fruentimmere, Dobbeltmoral, Usædelighedsforeninger og Skøjtebanens Friheder. Hovedvægten ligger altså mindre på kropskultur end på fornøjelser. Og så er forfatteren til dette udmærkede bind, Vagn Dybdal, i øvrigt fornyende og utraditionel i sit valg af emner.

I bind 13, Velfærdsstaten på Vej 1914-39, er idræt og kropskultur omtalt på en halv af de knap 500 sider.

I bind 14, der dækker årene 1940-65, er idrætten overhovedet ikke omtalt.

Går vi til det seneste værk om de sidste årtiers danske historie, Søren Mørchs Den ny Danmarkshistorie 1880-1960, fra 1982 er idrætten tildelt trekvart side ud af godt 400 - selv om denne fremstilling på mange måder er kættersk og utraditionel. Og denne trekvarte side er placeret mellem afsnit om Onani, Selvbesmittelse og En anden kønsmoral.

Så er idrætten, kropskulturen anbragt.

III

Det er ikke nogen tilfredsstillende placering. Ganske vist har vi fået Ove Korsgaards udmærkede pionerværk Kampen om Kroppen - en ambitiøs og dristig bog om dansk idræt gennem 200 år. Det er en oversigt, som vi ikke har haft før. Men den bygger ikke i større omfang på primær forskning.

For der er næsten ingen. Hvad man ikke kan laste Korsgaard for. Det er professionelle historikeres skyld, især de ansatte på universiteterne. De har ikke lavet deres arbejde med udforskningen af dansk historie ordentligt. Vi har ikke i tide fået en seriøs idrætshistorisk forskning i Danmark. Det er ikke kun synd. Det er værre: Manglen på idrætshistorisk forskning giver et fortegnet billede af udviklingen i det danske samfund gennem de sidste godt 100 år.

IV

Foruden kapitalen er der tre store folkelige bevægelser, der i denne periode afgørende har præget udviklingen i det danske samfund.

Det er højskole- og andelsbevægelsen, arbejderbevægelsen samt idrætsbevægelsen.

Af disse tre folkelige bevægelser sørgede højskole- og andelsbevægelsen tidligt for, at der kom en historisk forskning og i hvert fald en historieskriv- 
ning i gang. Derfor kom højskole- og andelsbevægelse tidligt med i almindelige menneskers historiske bevidsthed. Bevægelsen kom tidligt ind i skolebøgerne og i uddannelsessystemet.

Det var ikke overraskende, al den stund selve disciplinen historie indgik som et integreret og grundlæggende element $i$ hele bevægelsen. Uden historie og historisk bevidsthed ingen højskole- og andelsbevægelse.

Anderledes gik det med arbejderbevægelsens historie. Ganske vist var der også i denne bevægelses grundlæggende ideologi marxismen/socialismen et stærkt historisk baseret element, klasseanalysen. Men faghistorikerne herhjemme lod stort set arbejderbevægelsens historie ligge.

Historieskrivningen om arbejderbevægelsen var de officielle partihistorier og de lige så officielle historier om de enkelte fagforbund. De var næsten udelukkende skrevet af amatører og bevægelsens egne folk - og som regel i forbindelse med jubilæer og mindedage.

Det betød, at arbejderbevægelsen ikke kom med i de store samlede fremstillinger af Danmarks-historien - og heller ikke i de vigtige skolebøger. Det blev dokumenteret i den skolebogsundersøgelse, som fagbevægelsen satte i gang i begyndelsen af 70'erne. Den medvirkede til at sætte gang i udforskningen af arbejderbevægelsens historie. I den sidste halve snes år har det været et af de mest frugtbare områder i dansk historieforskning.

V

Idrættens eller kropskulturens historie i Danmark ligner forskningsmæssigt arbejderbevægelsens historie - for 15 år siden.

En del lokale fest- og jubelskrifter om foreninger og organisationer er skrevet af egne folk og amatører. Men den. er aldrig nået ind $i$ den professionelle historieskrivning, selv om nye tendenser er på vej, og slet ikke ind i skolebøgerne og folks historiske bevidsthed.

Det er beklageligt. For man kan dårligt diskutere den nutidige og fremtidige idrætspolitik seriøst uden at kortlægge præmisserne. De ligger også i fortidens udvikling.

En nøgle til forståelse af f.eks. den nuværende organisationsstruktur $i$ dansk idræt ligger ikke kun $i$ slagsmålet om ressourcer og personlige modsætningsforhold. Den ligger også i de ideologiske forskelligheder mellem organisationerne - $i$ deres forskellige tradition.

Med den plads kropskulturen i dag har fået, kan idrætshistorien bidrage væsentligt til forståelsen af det danske samfunds udvikling - også uden for baner og idrætshaller.

Det svenske eksempel er interessant. Fra 60'erne kom der store bevillinger fra Riksbankens Jubilæumsfond til udforskning af de tre store folkelige rørelser, der har været med til at udvikle det svenske samfund: Afholdsbevæ- 
gelsen, arbejderbevægelsen og idrætsbevægelsen. Millionbeløb blev investeret i projekterne, der resulterede $\mathrm{i}$ et halvt hundrede disputatser adskillige inden for idrætshistorien.

Herhjemme er der ikke større udsigt til at få finansieret et så storstilet projekt. Forskningsmidlerne er for små, slagsmålene om dem for store. Derimod kan man håbe på, at det opsving, som udforskningen af arbejderbevægelsen stod over for i 1970, nu ligger lige foran den danske idrætsbevægelses historie.

Eksemplet er værd at opholde sig ved.

VI

Udforskningen af arbejderbevægelsens historie i Danmark er blevet en bemærkelsesværdig succes. Med få midler opdyrkedes gennem 70'erne et nyt forskningsfelt, både professionelt på universiteterne og uden for blandt såkaldte amatørhistorikere. Man dannede et fællesfagligt selskab.

Midlerne var dels ABA, dvs. et fast arkiv (Arbejderbevægelsens Arkiv), dels en årbog, dels et regelmæssigt udkommende mindre skrift Meddelelser, begge af høj kvalitet. Hertil kom et årligt seminar og en række vigtige internationale kontakter. I dag er der 7-800 medlemmer og abonnenter og en frodig forskning.

Det var ikke udelukkende en succeshistorie. Fra starten var der en ikke unaturlig intern politisk rivalisering - både parti- og fagpolitisk. Det ny selskab mødte en vis mistænksomhed fra etablerede institutioner. Tydeligvis var de nervøse for en institutionskritisk holdning i forskningen. Der var politisk sprængstof $\mathrm{i}$ forskningsfeltet.

Først gradvist nåede selskabet accept og anerkendelse efter en halv snes års arbejde.

Internt løste selskabet de politiske rivaliseringer og holdt sig uden for alle omklamringer. Det forblev uafhængigt af organisationer. Økonomisk blev selskabet baseret på kontingenter og offentlige tilskud, bl.a. fra Nordisk Kulturfond, ikke fra organisationer og partier. Ingen fik lov at monopolisere forskningen eller selskabets aktiviteter.

Formentlig står vi foran et opsving i den idrætshistoriske forskning og interesse. Den udnyttes bedst ved at se på andres erfaringer. Her er fire bud til/på idrætshistorisk forskning - og et par advarsler:

- Undgå alle de forsøg på monopolisering og usund rivalisering, som altid optræder, når noget nyt opstår.

- Hold vandene åbne mellem professionelle historikere og amatørhistorikerne. Lokalhistorien og de såkaldte amatører er en del af faget. Den del er vigtig, både fordi den er folkelig og tilfører ny viden.

- Dyrk forbindelseslinierne til alle niveauer i uddannelsessystemet. Det er 
den vej, ny viden effektivt udbredes.

- Undgå fagchauvinismen. Hold vandene åbne til andre samfundsvidenskaber, især til idrætssociologi, etnologi m.v. Skellene er kunstige, når det gælder udforskningen af et så jomfrueligt område som idræt/kropskultur. Målet er opnåelse af ny viden - uanset hvor den kommer fra.

Og advarslerne.

For det første: De store teoretisk-akademiske diskussioner om afgrænsning af genstandsområdet for forskningsaktiviteten kan blive golde. Den akademiske venstrefløjs erfaringer i 70'erne er ikke opløftende. Meget endte i abstrakt skolastik, der både var lammende og ulæseligt. Hold balancen mellem empiri og den fakta-løse teoretiseren.

For det andet: Metode-diskussioner er væsentlige. Men der findes ikke een korrekt eller rigtig metode. Der findes mange muligheder. En given metode skal tilpasses det enkelte projekt alt efter problemet og kildematerialets karakter. Og så ændres den. Lad praksis vise metodernes frugtbarhed.

Og vigtigst: Der er opgaver nok til alle. Lad de 100 blomster blomstre. 


\section{Svommernes Dag.}

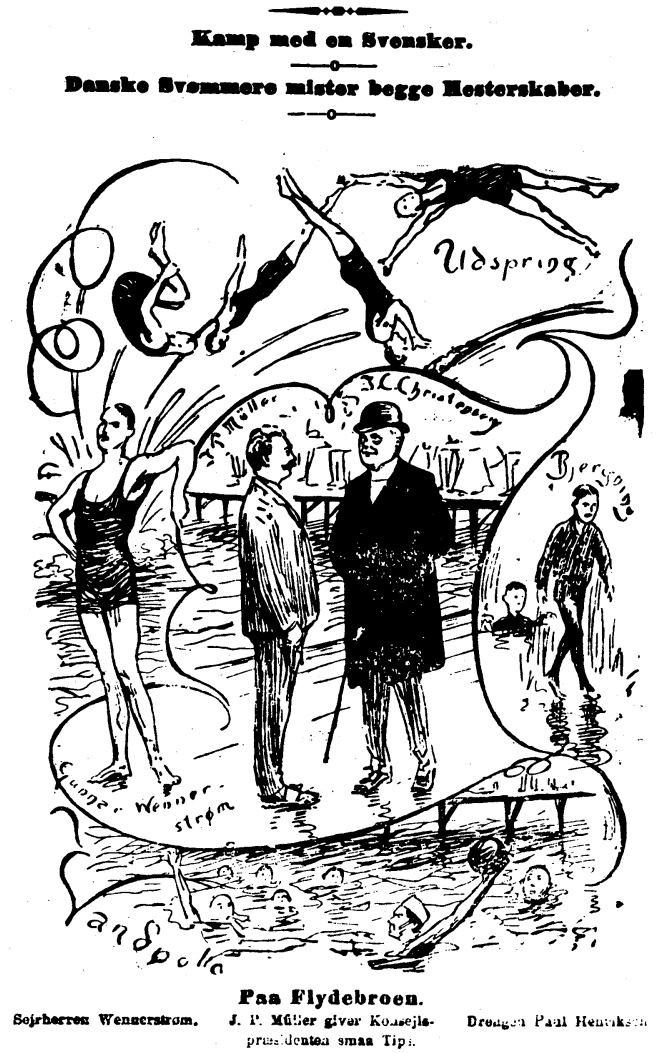

Svømmernes dag på Orlogsværftet (Pol. 7.8.1905). Som det fremgår er flere af sportstegningerne $i$ denne årbog sammensat af forskellige elementer. I centrum ses ofte en eller flere honoratiores. I dette tilfæ/de idrætsmanden og forfatteren J. P. Müller i selskab med konsejlpræsident J. P. Christensen. Konsejlpræsidenten har en, fremgår det, velkendt interesse for svømning omend ekcellencen ikke holder af selv at gå i vandet. Til venstre for centrum ses svenskeren Gunnar Wennerström, der vandt de to hovedløb. Først $100 \mathrm{~m}$ i 1 min. 26,5 sek., dernæst 1609 m (engelsk mil) i 29 min. 25 sek. Wennerström svømmede ,den engelske Sidesvømning med venstre Haand over Vandet i Fremtrækket og Saksebevægelse med Benene." Til højre for konsejlpræsidenten ses ,en lille 10-årig Fyr, Paul Henriksen, der tappert bjergede en langt større Kammerat, om han end var lidt længe om arbejdet". Tegning og artikel er i øvrigt, som det oftest er tilfældet i god overensstemmelse med hinanden. 